\title{
CARETAKER GOVERNMENT AND THE EVOLUTION OF CARETAKER CONVENTIONS IN NEW ZEALAND
}

\author{
Jonathan Boston, Stephen Levine, Elizabeth McLeay, Nigel S Roberts and \\ Hannah Schmidt*
}

Since the financial crisis immediately following the 1984 general election, various efforts have been made to clarify the role and responsibilities of caretaker governments in New Zealand. The need to do so was given added urgency as a result of the referendum in 1993 in favour of proportional representation. This article examines the recent evolution of New Zealand's caretaker conventions and assesses their application following the first MMP election in late 1996. The article begins with a brief description of caretaker conventions in other parliamentary democracies. It then considers the operation of the caretaker conventions in New Zealand under the previous first-past-the-post electoral system, and discusses the measures taken in the early-tomid 1990s to clarify these conventions in preparation for MMP. Having evaluated the conduct of government during the lengthy interregnum in late 1996, the article concludes with an analysis of some of the continuing policy issues generated by caretaker governments and outlines possible ways of reducing the frequency and duration of caretaker periods.

\section{INTRODUCTION}

In all parliamentary democracies situations arise, either after a general election or when a government loses the confidence of the legislature, where the existing administration operates - even if very briefly - in a "caretaker" capacity until a new government is sworn in. While New Zealand has no statutes pertaining to the powers of caretaker governments, various constitutional conventions have developed over the past century or so which apply in such situations. ${ }^{1}$ These conventions are comparable to those

* Professor of Public Policy, Associate Professor of Politics, Reader of Politics, Associate Professor of Politics and research assistant, respectively, Victoria University of Wellington. This article was prepared as part of "The New Zealand Political Change Project", a research programme examining the behavioural, institutional and policy consequences of MMP, funded by the Foundation for Research, Science and Technology. The authors wish to thank the Cabinet Office, Fiona Barker and Cate Nicholl for their invaluable assistance in the preparation of this article.

1 While the Cabinet Office Manual uses the label "caretaker convention" to describe the principles governing the actions of caretaker governments, this article will use the term "caretaker 
in many other democratic states, especially in relation to the requirement for incumbent administrations to maintain the policy status quo (ie that which existed prior to the government assuming a caretaker role) and exercise restraint when dealing with matters of political significance. As a result of the brief, but acute, financial and constitutional difficulties which arose following the general election in 1984 and the political uncertainty generated by the 1993 election results, it became evident that greater clarification of the caretaker conventions was required. This task was made all the more pressing given the prospect that the new mixed-member proportional (MMP) electoral system, introduced in 1996, would produce longer periods of transition from one government to the next.

This article examines the evolution of New Zealand's caretaker conventions and assesses their application following the first MMP election in late 1996. The article begins with a brief description of caretaker conventions in other parliamentary democracies. Next, it examines the operation of the caretaker conventions in New Zealand under the previous first-past-the-post electoral system, and outlines the actions that were taken in the early-to-mid 1990s to clarify these conventions in preparation for the introduction of MMP. The article then evaluates the operation of the caretaker conventions during the lengthy interregnum in late 1996, and considers whether the existing conventions are sufficiently robust to deal with the full range of political contingencies which might occur in the future under proportional representation.

\section{INTERNATIONAL EXPERIENCE}

The international academic literature on caretaker government is exceptionally thin. Indeed, many standard texts on the constitutional practices and procedures of particular democratic states either do not mention, or only fleetingly discuss, the nature and frequency of caretaker periods and the proper role of, and constraints upon, caretaker governments. ${ }^{2}$ Likewise, even the political science literature on government formation

conventions", in line with international practice.

2 We have located only one academic study which compares and contrasts the constitutional provisions relating to caretaker governments in parliamentary democracies. See M Laver and K Shepsle (eds) Cabinet Ministers and Parliamentary Government (Cambridge University Press, New York, 1994) 291-2. Standard works on British government, such as J Mackintosh The British Cabinet (Stevens \& Sons, London, 1977), do not mention the topic, and there is only brief reference to the subject in recent New Zealand constitutional texts, such as $\mathrm{P}$ Joseph Constitutional and Administrative Law in New Zealand (Law Book Company, Sydney, 1993). Government transitions are, however, discussed by K Jackson "Government Succession in New Zealand", (1977) 15 Journal of Commonwealth and Comparative Studies 151-69; and by E McLeay The Cabinet and Political Power in New Zealand (Oxford University Press, Auckland, 1995) 27-31. 
and termination - which is extensive - gives surprisingly little attention to the nature and implications of caretaker government. ${ }^{3}$

Despite the relative dearth of material, it appears that most parliamentary democracies have developed explicit conventions to guide the actions of caretaker governments. ${ }^{4}$ Typically, such conventions require, amongst other things, that incumbent governments should remain in office until a new administration is sworn in. While caretaker governments are generally deemed to have full executive powers, it is expected that they should not embark upon major new policy initiatives. ${ }^{5}$ In effect this means that significant policy matters not requiring immediate decisions should be left for the new government to deal with. Exceptions to such rules normally arise only when the caretaker period is protracted (ie more than several months).

Of course, determining what it means to preserve the "policy status quo" under a caretaker government is not always clear cut. The dominant view in the literature is that there should be no change from the policy position "that was in place when the outgoing government lost its parliamentary basis". ${ }^{6}$ Presumably this means that a policy which has already been announced but not fully implemented should proceed. But this policy may have been the subject of significant political controversy - indeed, it may have sparked the fall of the government - and there may, accordingly, be strong pressures on a caretaker government to delay, or alter the process of, policy implementation. Another implication of preserving the policy status quo is that a caretaker government cannot respond to new situations and issues in the manner in which it might have done had there been no question over its parliamentary position. In this sense, therefore, "the caretaker government represents less than the policy position of the outgoing government".

While periods of caretaker government occur in all parliamentary democracies, they tend to be both more frequent and more protracted in countries with proportional representation. This is because election outcomes are less clear cut with the result that government formation is more complex and time consuming. Governmental durability

3 See for instance W Müller and K Strøm (eds.) Koalitionsregierungen in Westeuropa: Bildung, Arbeitsweise und Beendigung (Signum Verlag, Wien, 1997).

4 M Laver and K Shepsle, above n 2, 292.

5 According to Laver and Shepsle, of 14 parliamentary democracies (including New Zealand) surveyed in the mid-1990s, the convention that caretaker governments should avoid taking important decisions applied in all cases except Germany and Ireland (and France during the Fourth Republic). Above n 2, 292.

6 Above n 2, 292.

7 Above n 2, 292 
also tends to be lower in countries with proportional representation than those with firstpast-the post electoral systems. For such reasons, countries with proportional representation have a greater need for clear caretaker conventions.

It may be useful at this juncture to outline briefly the nature and application of caretaker conventions in a range of parliamentary democracies: first, Australia and Canada (which like New Zealand have been influenced strongly by the Westminster tradition); and second, a number of countries with systems of proportional representation.

In Australia the caretaker conventions operate from the time Parliament is dissolved until either a new government is sworn in or the election results confirm that the existing administration will remain in office. ${ }^{8}$ Wherever possible, incumbent governments are expected to avoid issues of significance, such as taking major policy decisions which are likely to commit the next government, making important appointments and entering into major contracts. Very similar conventions apply in Canada. On the one hand, an incumbent administration in Canada "retains its full legal authority to carry on the government of the country and remains fully responsible for ensuring the provision of effective government, until a new government is sworn in". ${ }^{9}$ On the other hand, such a government is expected to show restraint. The precise nature of this restraint is, of course, a matter of political judgement. Where the incumbent government has been clearly defeated in the House or in an election, the expectation of restraint is all the stronger. In these cases, only "urgent, routine, non-controversial and 'reversible' decisions would be considered appropriate". ${ }^{10}$

Turning to countries with proportional representation: in Norway there is a fixed parliamentary term and general elections are held every four years in mid-September. Following the election the incumbent government is required to continue in office until a new administration has been formed. Moreover, even if the government has been defeated at the election or for other reasons wishes to resign, it is required to present the annual Budget in early October before the new administration is sworn in. Thus, a postelection caretaker period can typically last about a month. While the Norwegian constitution "does not recognize any particular rules or constraints concerning caretaker

8 State Services Commission Working Under Proportional Representation: A Reference for the Public Service (Wellington, 1995) 137-8. However, governments are also expected to constrain their actions from the time the election is announced until the dissolution.

9 Machinery of Government Secretariat Major Actions by a Government Before an Election and During Transition (Machinery of Government Secretariat, Privy Council Office, Ottawa, 1997) 1.

10 Above n 9, 2. 
governments", 11 conventions nevertheless dictate that it should refrain from taking significant decisions. ${ }^{12}$

In Sweden, while the only constitutional difference between ordinary and caretaker governments is that the latter cannot dissolve Parliament, in practice caretaker governments constrain their actions to administrative matters and avoid presenting bills to Parliament. However, Larsson suggests that if an incumbent government were required to remain in office for a number of months (instead of the usual two-to-three weeks) it would operate "more and more like an ordinary cabinet". ${ }^{13}$ This, in fact, appears to be the case in the Netherlands, where it is not unknown for the process of government formation to take six months, or even longer. Not surprisingly, in such circumstances, Dutch caretaker administrations are obliged to govern in a relatively "normal" fashion. Thus, the legislative process continues, with new legislation being drafted and presented to Parliament: "budgets are introduced, subsidies are handed out and appointments are made". ${ }^{14}$ Important political decisions are, of course, only made after detailed inter-party consultations.

Of the countries with proportional representation for which information could be obtained, only Germany and Ireland appear to have no statutory provisions or wellestablished conventions imposing a limitation on the behaviour of caretaker governments. In the case of Germany, the potential difficulties generated by caretaker periods are fewer than in many other jurisdictions because changes of government between elections require a "constructive vote of no-confidence". Accordingly, no government can lose the confidence of the legislature between elections without this confidence being simultaneously transferred to an alternative government. Thus, although an outgoing government acts in a caretaker capacity while a new government is being formed, there will be no doubt over the nature of this new government. Inter-party consultations on any important policy matters which might arise during this period can thereby be conducted in a relatively certain political context. Having said this, there is still the potential in Germany for significant political uncertainty after a general election,

11 Kaare Strom "The Political Role of Norwegian Cabinet Ministers", in M Laver and L Shepsle (eds) Cabinet Ministers and Parliamentary Government (Cambridge University Press, New York, 1994) 41.

12 For in-depth analysis of practices in various countries, see J Boston Government Formation: International Comparisons and Lessons for New Zealand (Victoria University of Wellington, unpublished paper, 1997); above n 8, particularly 101-128 and 137-8.

13 T Larsson "Cabinet ministers and parliamentary government in Sweden", in M Laver and K Shepsle (eds) Cabinet Ministers and Parliamentary Government (Cambridge University Press, New York, 1994) 172.

14 R Andeweg "The Netherlands: Coalition Cabinets in Changing Circumstances", in J Blondel and F Muller Rommel (eds) Cabinets in Western Europe (Houndmills, Macmillan, 1988) 60. 
and it is not uncommon for a caretaker period to last for up to six weeks while a new government is being formed. For various reasons, however, most elections during the post-war era have produced clear-cut outcomes in the sense that the likely composition of the new government has been evident as soon as the results of the election have been determined. Consequently, caretaker periods have not generated major political difficulties.

In Ireland, while "acting" or caretaker governments are specifically referred to in Article 28.11.1 of the country's Constitution, there is no constitutional limitation on the powers of such governments. Perhaps partly for this reason, as Laver notes, "Irish caretaker Governments have not shrunk from using the full powers available to them ... with little regard to their caretaker status". 15 This has included making various appointments to statutory boards for reasons that can only be regarded as political. In order to prevent such behaviour, Laver has suggested that Ireland should follow Germany in introducing a constructive vote of no-confidence and that the Constitution should be amended so that caretaker administrations are limited to making decisions which are "required to ensure the essential good government of the State". ${ }^{16}$

\section{CARETAKER GOVERNMENT IN NEW ZEALAND}

\section{A Caretaker Government under First-Past-the-Post}

One of the fundamental principles of responsible government in New Zealand is that the government must hold the confidence of the House of Representatives in order to remain in office. There are, however, circumstances where it may be necessary for an administration which does not clearly have such support to "remain in office on an interim basis until the situation is clarified". ${ }^{17}$ During such periods the incumbent administration is required to act in accordance with the caretaker conventions. In practice this means that while the government continues in office as the legal authority and retains full executive powers (in accordance with the constitutional requirement that the Governor-General be supplied with ministerial advisers at all times), its actions are expected to be constrained on matters of political significance so as not to inappropriately embarrass or bind an incoming government. ${ }^{18}$

15 M Laver "The government formation process in Ireland: implications for the constitutional role of the President, the Government and the Dail", in Report of the Constitution Review Group (The Stationery Office, Dublin, 1996) 479.

16 Above $\mathrm{n} 15,480$.

17 Cabinet Office Manual (Cabinet Office, Wellington, 1996) para 2.35.

18 M Hardie Boys Continuity and Change: The 1996 General Election and the Role of the Governor-General (1997) 4 Waikato LR 1, 4; G Palmer and M Palmer Bridled Power: New Zealand Government under MMP (Oxford University Press, Auckland, 1997) 34; above n 8, 75-85; above n 17. 
The application of the caretaker conventions was generally straightforward under the first-past-the-post electoral system since one of the two major parties - National or Labour - usually secured a majority of parliamentary seats on election night. Such clear outcomes generally allowed for an expeditious and straightforward transition of power from the outgoing to the incoming government. Accordingly, transitional periods tended to be uncontroversial and were relatively brief, typically lasting no more than two weeks until the return of the writs (ie the final presentation and certification of the election results) and the swearing-in of the new cabinet.

However, in July 1984 the caretaker conventions were severely tested when considerable uncertainty arose over whether the incumbent administration was obliged to act on the advice of the incoming government. On election night it was evident that the National government, which had been in office for almost nine years, had been defeated by Labour in a landslide victory. Complications arose, however, because of significant pressure on the New Zealand dollar during the election campaign, prompted in part by the widespread expectation that a Labour government would devalue the currency. By the end of the campaign, New Zealand faced a serious exchange rate crisis, and the day after the election the Reserve Bank was forced to suspend all foreign exchange dealings in order to halt a run on the currency. ${ }^{19}$ In the days immediately following the general election the Reserve Bank advised that urgent government action was required to devalue the New Zealand dollar. Sir Robert Muldoon, the outgoing Prime Minister and Minister of Finance, disagreed with this advice and initially refused to execute any decisions made by the incoming government - in his view he was still the Prime Minister of the legal government. To complicate matters further, it was not possible for a new government to be sworn in until after the return of the writs, at least ten days later. The situation was resolved three days after the election when Muldoon - under pressure from senior colleagues - relented and agreed to act on the advice of the incoming government.

While a protracted constitutional and financial crisis was avoided, the events of mid1984 highlighted the lack of certainty surrounding the authority and responsibilities of a defeated government that had not yet been formally replaced by a new administration. In order to clarify matters and resolve some of the wider constitutional issues raised by the 1984 crisis, the Labour government established an Officials Committee on Constitutional Reform. ${ }^{20}$ In its first report in 1986, it argued that an outgoing government's conduct during a caretaker period is subject to several significant constitutional constraints:

19 G Palmer and M Palmer, above n 18, 34.

20 G Palmer Unbridled Power: An Interpretation of New Zealand's Constitution and Government (Oxford University Press, Auckland, 1987) 34-8; M Hardie Boys, above n 18, 4. The situation in 1984 also led to the setting out of the general rule - in the Constitution Act 1986 (s 6) - that Ministers must be Members of Parliament, and determined the position that defeated Ministers may continue to hold 
(a) It will undertake no new policy initiatives.

(b) It will act on the advice of the incoming government on any matter of such great constitutional, economic or other significance that it cannot be delayed until the new government formally takes office - even if the outgoing government disagrees with the course of action proposed. ${ }^{21}$

It is important to note that the wording adopted by the Officials Committee corresponded closely to that employed at the time of the 1984 crisis by the outgoing Attorney-General, Jim McLay, in a press statement issued three days after the general election. Subsequently, the same conventions were explicitly accepted by both the Labour and National parties at the change of government in October 1990, and were incorporated into the Cabinet Office Manual. ${ }^{22}$ Accordingly, by the time of the introduction of MMP it can be argued that they were well established conventions.

But what of the constitutionality of Sir Robert Muldoon's actions? From the standpoint of subsequent developments it is evident that while he did not violate the first convention, he certainly did breach the second. Yet at the time, of course, neither of these conventions were well established in New Zealand, and indeed the second convention had not hitherto been stated explicitly in the form employed by McLay and endorsed by the Officials Committee. ${ }^{23}$ Against this, there were precedents for both conventions in other Westminster systems. In Australia, for instance, the incumbent Prime Minister, Malcolm Fraser, followed the request of the incoming Labor administration in 1983 to devalue the Australian dollar. ${ }^{24}$ Further, to the extent that constitutional conventions simply reflect and seek to clarify what is deemed by most people to be "reasonable" or

office until the 28th day after the day on which they ceased to be a Member of Parliament.

21 Constitutional Reform: Reports of an Officials Committee - First Report (Department of Justice, Wellington, 1986) para 4.3.

22 State Services Commission, above n 8, 77; above n 17, para 2.36 - 2.37.

23 J Boston, S Levine, E McLeay and N S Roberts New Zealand Under MMP: A New Politics? (Auckland University Press, Auckland, 1996), 111; C James Under New Sail: MMP and Public Servants (Institute of Policy Studies, Wellington, 1997), 50; G Palmer, above n 20, 35 . Marshall has noted that "politicians" doubts about what ought to be done may stem not from uncertainty about whether duty-imposing conventions are morally binding but from disagreement as to whether a particular convention does or does not exist. Since opposed politicians are rarely likely to convince each other on this point an advisory jurisdiction, selectively used, seems a useful device in any political system where important constitutional rules are conventional and uncodified". See G Marshall "Constitutional Conventions - The Rules and Forms of Political Accountability" in M Chen and G Palmer (eds) Public Law in New Zealand: Cases, Materials, Commentary and Questions (Oxford University Press, Auckland, 1993). 
commonsense political practice, it can be argued that a government which has clearly lost its electoral mandate should defer to the policy preferences of its soon-to-be appointed successor if urgent decisions are required during any transitional period. On this score, Muldoon was plainly wrong in his initial refusal to act in accordance with Labour's wishes, however inappropriate or misguided he believed a devaluation of the dollar would be.

\section{B The Transition to MMP 1993 - 1996}

The political situation following the 1984 general election was in one sense relatively straight-forward: it was clear on election night that the National government had lost its parliamentary majority and equally clear that another party, Labour, had won sufficient seats to form a stable, single-party majority government. By contrast, the immediate outcome of the 1993 general election was far from certain, with neither of the major parties having secured a majority in its own right or being clearly in a position to command the confidence of Parliament (ie with the support of another party or parties). The eventual outcome would thus depend on the results of special votes in a number of key marginal seats and possibly also on the views of the two minor parties which had secured seats - the Alliance and New Zealand First.

Given these uncertainties, the meaning and application of the caretaker conventions again became a politically salient issue. In order to help clarify matters, a Cabinet Office circular was released several days after the election setting out criteria for Cabinet and Ministerial decision-making. ${ }^{25}$ These guidelines were later incorporated into the 1996 Cabinet Office Manual. In brief, the new guidelines indicated that where the identity of the new government was unclear, a caretaker government should refrain from significant decisions. ${ }^{26}$ In circumstances where an urgent decision was required, interim measures were to be implemented which did not require a long-term commitment by the government. And if such arrangements were not possible or appropriate, then the caretaker administration should make the necessary decisions but only after consultation with opposition party leaders. The guidelines left it to the judgement of the caretaker government to determine precisely what matters required consultation and with which parties consultation should occur. As matters transpired, the final election results awarded National a slender parliamentary majority and the caretaker situation lasted less than two weeks.

The outcome of the general elections in 1984 and 1993 not merely provided a foretaste of the kinds of issues which were likely to arise under MMP but also supplied the

25 Cabinet Office Circular, CO (93) 18 (Cabinet Office, Wellington, 9 November, 1993).

26 Above n 17, para 2.38 . 
necessary political incentive for a more careful formulation of the conventions governing caretaker administrations. In the process, it came to be recognized that there were two separate sets of circumstances in which such conventions might apply; these were subsequently referred to in the Cabinet Office Manual as the "two arms to the convention". ${ }^{27}$ The first "arm", as it is called, applies to situations where the identity of the next government is clear but it has yet to take office; the second "arm" applies when it is not clear who will form the next government. Obviously, such uncertainty can arise either after a general election or when a government loses the confidence of the House part-way through its parliamentary term.

In preparation for $\mathrm{MMP}$, and in particular the possibility of greater political uncertainty and lengthy caretaker periods, further consideration was given by officials and Ministers during the transition Parliament (1993-96) to the constitutional implications of electoral reform. This included further exploration of the issues relating to the conduct and responsibilities of caretaker administrations. ${ }^{28}$ As a result, a major report - Working Under Proportional Representation: A Reference for the Public Services - was prepared by officials, endorsed by the Cabinet and published by the State Services Commission in September 1995.

In relation to caretaker periods, the Report enunciated five main principles:

- The Governor-General is not to be left without responsible advisers (ie Ministers);

- $\quad$ The day-to-day business of government must continue;

- An outgoing government is still the legitimate executive authority because its Ministers continue to hold their appointments under the authority of the Crown;

- An incumbent government, where that government has either lost the confidence of the House, or where it is unclear who can command the House's confidence, does not have a mandate to implement new policies or take major decisions such as approving significant appointments and contracts;

- If the make-up of the new government is not certain, the caretaker government should defer all significant decisions where possible. If an immediate and final decision is required on a matter of long-term significance, the incumbent

27 Above n 17, paras 2.36-2.38.

28 See J Boston et al, above n 23; J Boston, S Levine, E McLeay, N S Roberts and H Schmidt "The Impact of Electoral Reform on the Public Service: The New Zealand Case", Australian Journal of Public Administration (forthcoming 1998). 
administration may consult other parties to see whether a proposed action has the support of the House. ${ }^{29}$

Additionally, the Report specified in some detail the responsibilities of public servants during caretaker periods. This material drew upon and developed previous advice, such as that issued by the State Services Commissioner in early November 1993 in response to the political uncertainty surrounding the 1993 general election. During the transition to MMP the Cabinet Office also issued, with the approval of the Cabinet, a series of circulars covering such topics as decision-making by Cabinet and Ministers following final election results; the handling of requests made under the Official Information Act 1982; the conduct of the public service during periods of caretaker government; constitutional procedures after the general election; and the continuation of government business. ${ }^{30}$

\section{A The First MMP Caretaker Government}

As anticipated, the general election held on 12 October 1996 failed to provide any single party with a clear parliamentary majority. The two major parties, National and Labour, won 44 and 37 seats respectively in the 120-member legislature, with the centrist New Zealand First party holding the balance of power with 17 seats. ${ }^{31}$ Shortly thereafter negotiations were conducted in a parallel manner between Labour and New Zealand First, and between National and New Zealand First-a process of government formation without precedent in New Zealand. ${ }^{32}$ The establishment of a centre-right majority coalition between National and New Zealand First was eventually announced by New Zealand First's leader, Winston Peters, on 10 December 1996.

While it was widely expected that the interregnum would be longer than the twoweek period typical under first-past-the-post, few envisaged that it would last for two

29 Above $n$ 8, 77.

30 See, for instance, Cabinet Office Circular, CO (93) 17 (Cabinet Office, Wellington, 8 November, 1993); Cabinet Office Circular, CO (93) 19 (Cabinet Office, Wellington, 17 November, 1993); Cabinet Office Circular CO (93) 20 (Cabinet Office, Wellington, 18 November, 1993); Cabinet Office Circular CO (95) 15 (Cabinet Office, Wellington, 19 December, 1995); Cabinet Office Circular, CO (96) 10 (Cabinet Office, Wellington, 3 September, 1996); Cabinet Office Circular, CO (96) 12 (Cabinet Office, Wellington, 14 October, 1996); Cabinet Office Circular, CO (96) 13 (Cabinet Office, Wellington, 23 October, 1996); Cabinet Office Circular, CO (96) 14 (Cabinet Office, Wellington, 1 November, 1996); Cabinet Office Circular, CO (96) 16 (Cabinet Office, Wellington, 11 December, 1996).

31 J Boston, S Levine, E McLeay and N S Roberts (eds) From Campaign to Coalition: New Zealand's First General Election under Proportional Representation (Dunmore Press, Palmerston North, 1997) 10, 210.

32 For more information on the process of government formation in 1996 see J Boston and E McLeay "Forming the First MMP Government: Theory, Practice and Prospects" in J Boston, S Levine, E McLeay and N S Roberts (eds) From Campaign to Coalition: New Zealand's First General Election under Proportional Representation (Dunmore Press, Palmerston North, 1997) 207-246. 
months (which is significantly longer than in most other countries with proportional representation). There were a number of reasons for such a lengthy period of caretaker government. Significantly, New Zealand has no legal constraints on the time taken to form a government. Although section 19 of the Constitution Act 1986 requires Parliament to meet within approximately eight weeks of the general election, in theory Parliament could assemble, MPs could be sworn in, the Speaker appointed, and then the House could adjourn with the issue of who will form the next government being left until some other occasion. ${ }^{33}$ Further contributing elements were New Zealand First's desire for a detailed coalition agreement, the fact that party negotiators had very little experience of coalition negotiations to draw upon, and the lack of pre-determined alignments amongst the parliamentary parties.

Constitutionally, the first caretaker period under MMP was similar to that in 1993 in the sense that it was uncertain which party or parties would form the next government. There were, however, two key differences. First, the protracted nature of the interregnum in 1996 tested the conventions more rigorously. Second, the political dynamics were significantly different: whereas the balance of power on election night results in 1993 apparently lay with two small parties (ie the Alliance and New Zealand First), in 1996 a single party, New Zealand First, held the key to the character of the next government. Not unexpectedly, this put pressure on the caretaker government to refrain from actions which might complicate the National party's negotiations with New Zealand First. ${ }^{34}$

In order to minimize any constitutional or policy dilemmas which could arise during a potentially lengthy caretaker period, the National/United coalition government brought forward as many decisions as possible in the months preceding the 1996 general election. It also endeavoured to identify those decisions which could be deferred until the new government took office. ${ }^{35}$ Partly as a result of such actions, and partly also due to good fortune (eg the absence of international crises or politically divisive domestic events requiring urgent government attention), the caretaker period generated relatively little political controversy: routine government business continued; the Cabinet policy process remained in operation, albeit at a much reduced scale and pace; preparations for the 1997 budget were largely put on hold; and senior Ministers devoted much of their energies to the coalition negotiations. Overall, most Ministers appear to have adopted a "conservative" or "restrictive" view of their powers and there was little deliberate testing of the boundaries of the caretaker conventions. ${ }^{36}$

33 J Boston and E McLeay, above n 32, 209.

C James, above n 2332 .

C James, above $n 23,37$. 
Nonetheless, the caretaker period did not proceed entirely without incident. At various stages one or other of the opposition parties complained of inconsistent or inappropriate behaviour by the incumbent administration. In many ways such complaints were unsurprising. After all, the caretaker conventions, as developed in the mid-1980s and early 1990s, are expressed in relatively general terms and are thus open to varying interpretations. Indeed, as the Cabinet Office Manual emphasizes, their application requires the use of discretion and political judgement by caretaker Ministers. ${ }^{37}$ Such judgement must be exercised on a range of issues including:

- whether a particular proposal or initiative constitutes a genuinely new matter or whether it is consistent with, and perhaps merely an extension of, an existing policy;

- whether the matter in question is politically significant (or likely to become significant);

- whether, and to what extent, a particular decision is reversible, and whether it will improperly bind the next government;

- whether a decision can be delayed without causing unnecessary administrative difficulties or imposing unreasonable costs;

- whether consultation with opposition parties should occur, and if so on what basis and with which particular parties; and

- what degree of agreement is required amongst the parties before a decision can be taken.

Judging by the actions of various Ministers during the caretaker period in late 1996, there were differences over a number of these issues, including the question of what constitutes a matter of political (or policy) significance requiring consultation with opposition parties, what constitutes an existing (ie pre-election) policy as opposed to a new policy, and whether potentially significant but uncontroversial matters should be the subject of inter-party consultations. For instance, the Minister of Education, Wyatt Creech, delayed his announcement of the annual funding allocations for individual tertiary institutions while he consulted with opposition parties. ${ }^{38}$ In so doing, he made forward planning by tertiary institutions for the 1997 academic year all the harder. Yet whether such consultations were necessary, in terms of the caretaker conventions, is open to question given that annual funding allocations of this nature essentially involve the implementation of a pre-existing policy for which Parliament has already voted (most of)

37 Above n 17, para 2.46. 
the necessary funds. Moreover, in the particular case in question the Ministry of Education had already made recommendations in relation to the relevant funding allocations prior to the election and there was little prospect of opposition parties dissenting from the proposed course of action.

In another instance the then Minister of Health, Jenny Shipley, directed the Southern Regional Health Authority (SRHA) to defer its decision to award a contract for cardiac surgery (which involved a participant from the private sector). The Minister's intervention was based on the fact that a decision by the SRHA could bind the next government to a policy which it did not support; this was indeed a strong possibility, given New Zealand First's opposition prior to the election to any private participation in the delivery of public health services. Interestingly, while the Minister was correct in her reasoning that the incumbent government should avoid taking decisions which might inappropriately bind the next administration, it could be argued that the letting of the contract would not have been in contradiction with the caretaker convention, since it was a continuation of pre-existing policy (ie that the SRHA should have discretion over the awarding of contracts of this nature). In fact, since the SRHA had already been in the process of negotiating the contract prior to the election, the Minister in effect reversed a pre-election decision. Such an instance highlights the potential tensions which can arise between, on the one hand, the desire to preserve the policy status quo and, on the other hand, the desire to avoid decisions being taken which limit the freedom of action of the incoming government. In the case in question, the Minister was almost certainly correct in giving overriding importance to the need to avoid a decision by the SRHA that would have generated difficulties for the new government.

Several other pre-existing policies were also reversed. ${ }^{39}$ Amongst these were the incumbent government's decision to withdraw from a case before the Privy Council (largely as a result of a request by New Zealand First) and the decision by the Minister of Crown Health Enterprises, Bill English, to direct the Hawkes Bay Crown Health Enterprise not to close wards at Hastings hospital.

By contrast to the decisions of some Ministers to reverse pre-existing policies (sometimes with little consultation) or to defer relatively urgent matters until a new government had taken office (such as the decision not to intervene in the deepening financial crisis afflicting Capital Coast Health in Wellington), others chose to consult opposition parties on "new" policy matters in the interests of reaching a consensus or at least making a decision more politically acceptable. For example, the Minister of Defence, Paul East, agreed to consult other parties prior to a final decision being taken over New

39 C James, above n 23, 32. See also J Taylor Executive Decision Making During Post-Election Periods of Caretaker Government Under MMP (Honours essay, School of Political Science and International Relations, Victoria University of Wellington, 1997). 
Zealand's aid contribution to the African humanitarian crisis. Similarly, the Minister of Transport, Maurice Williamson, sought the support of New Zealand First and Labour to attend a Transport Ministers conference in Australia in mid-November. The Minister of Labour, Doug Kidd, also announced that other parliamentary parties would be consulted if a decision over an increase in the minimum wage became necessary.

As noted, inconsistencies of this nature - whether apparent or real - are almost inevitable during any moderate-to-lengthy period of caretaker government since Ministers are bound to differ in the way they interpret and apply the relevant conventions. To some degree, of course, any divergence between Ministers will be moderated via the process of Cabinet consultation and collective decision making. Nonetheless, different approaches are bound to occur during an interregnum of the kind witnessed in late 1996. The main safeguard in these circumstances is that the behaviour of Ministers - whether acting individually or collectively - remains the subject of ongoing political scrutiny. Accordingly, where decisions are plainly inconsistent or clearly breach the caretaker conventions the incumbent administration is likely to incur political costs potentially, in extreme cases, of a long term and significant nature.

Ministers in late 1996 were not alone in having different views on how the caretaker conventions should be applied in certain situations. A similar divergence was evident at a seminar on caretaker government attended by senior officials and academics at the Institute of Policy Studies at Victoria University of Wellington in April 1997, four months after the first MMP government took office. ${ }^{40}$ James identified two distinct schools of thought amongst those at the seminar: the "pragmatists" and the "constitutionalists". ${ }^{41}$ According to the pragmatists, who represented the majority view at the gathering, the conventions need to be applied in a manner which ensures that there is neither an excessive use of power nor a failure by a caretaker government to exercise its legal authority where decisions are required. In determining whether consultation with opposition parties is required, the pragmatists argued that there were three important criteria: first, whether the matter was of political significance; second, whether a particular course of action was ultimately likely to secure a parliamentary majority; and third, whether the matter was readily reversible. It was contended that consultations should certainly occur when an issue was significant and controversial and if the proposed course of action would be difficult to reverse. The Cabinet, however, should be free to act without extensive consultation if an issue was relatively trivial, or - in the case of a significant issue - if there was likely (on the basis of publicly-stated policy positions

40 C James, above n 23, 32-5.

41 Above n 23, 32. 
by the various parties) to be a clear majority in the new Parliament for the proposed course of action.

By contrast, the constitutionalists argued that a caretaker government should not interfere with any existing (ie pre-election) policies without parliamentary authority, since a caretaker government requires the "imprimatur of the new Parliament to override the old". ${ }^{2}$ From this standpoint, a decision to reverse the policy of the previous government in the absence of a clear parliamentary mandate (or at the very least extensive consultations with most, if not all, of the other parliamentary parties) would breach the convention and would thus be improper. Accordingly, Shipley's intervention in relation to the SRHA, which occurred in the absence of wide-ranging consultations, was questionable.

In our view, the position advanced by the so-called "constitutionalists" is unduly restrictive, particularly where the caretaker period is protracted because of difficulties forming a new government. Also, it must be recognized that the policy positions of the main parliamentary parties on most issues are generally well known. Having said this, a good case can be made for caretaker administrations erring on the side of caution and consulting excessively rather than minimally.

\section{CONTINUING ISSUES}

Standing back from the particulars of the 1996 caretaker period there are number of broader issues in relation to the caretaker conventions which require brief comment. The first concerns the definition of a caretaker period. It is generally accepted that the full caretaker conventions apply in at least two situations: first, the period between a general election and the swearing in of a new government; and second, the period between an incumbent government resigning or losing a vote of no-confidence in Parliament and the formation of a new government. ${ }^{43}$ There is less agreement, however, as to whether the conventions should apply in two other situations: (a) the period between the dissolution of Parliament and a general election where the incumbent government still enjoys the confidence of the House; and (b) the period between the announcement of an election and the dissolution of Parliament.

In Australia, for instance, the caretaker conventions apply from the date of the dissolution of the House of Representatives (irrespective of the cause of the dissolution) "until either a new government has been sworn in or the election results confirm that the

42 C James, above n 23, 52. Interestingly, however, Parliament was not convened in 1996 until the last day permitted under the Constitution Act, which meant that a parliamentary majority could only be tested via consultation.

43 J Boston et al, above n 23, 110; State Services Commission, above n 8, 81-82. 
existing Government will remain in office". ${ }^{44}$ Further, it is expected that the incumbent government will exercise additional caution during the period between the announcement of an election and the dissolution of the House. In New Zealand, by contrast, the official view, as expressed in the Cabinet Office Manual, is that the "full" caretaker convention does not apply prior to an election unless the government has lost the confidence of the House. ${ }^{45}$ However, the Manual notes that "successive governments have restricted their actions to some extent at this time, in recognition of the fact that an election, and therefore potentially a change of government, is imminent". ${ }^{4}$ Such restrictions, which have applied to a period of up to three months prior to the date when an election is due, have included the deferral of significant appointments and the cancellation of some government advertising. Table 1 sets out the current constitutional position, at least as enunciated in the Cabinet Office Manual.

In our view, it would be desirable for there to be greater clarity over the circumstances during which the caretaker conventions apply, whether fully or partially. While there are plainly a range of possibilities, it is our view that the Australian approach has merit and should be applied in New Zealand. Accordingly, the full caretaker conventions should take effect as soon as the House is dissolved, irrespective of the reasons for the dissolution. Additionally, governments should be expected to observe a degree of self-restraint in the period leading up to a dissolution, particularly when the likely date of such a dissolution is readily apparent.

Table I Varieties of Caretaker Government in New Zealand

\begin{tabular}{||l|l|l|l|l||}
\hline \hline & $\begin{array}{l}\text { Governing } \\
\text { during an } \\
\text { election } \\
\text { campaign }\end{array}$ & $\begin{array}{l}\text { Governing } \\
\text { after an } \\
\text { election while } \\
\text { awaiting a new } \\
\text { known } \\
\text { incoming } \\
\text { government }\end{array}$ & $\begin{array}{l}\text { Governing after } \\
\text { an election } \\
\text { when the } \\
\text { identity of the } \\
\text { new } \\
\text { government is } \\
\text { undecided }\end{array}$ & $\begin{array}{l}\text { Governing } \\
\text { during period } \\
\text { of mid-term } \\
\text { instability }\end{array}$ \\
& &
\end{tabular}

\footnotetext{
44 State Services Commission, above n 8, 82 .

45 Above n 17, para 2.42.

46 Above n 17, para 2.42.

47 Mid-term instability includes a coalition split, followed by vote of no confidence, or simply a defeat of the government.
} 


\begin{tabular}{|c|c|c|c|c|}
\hline Conventions & $\begin{array}{l}\text { Modified } \\
\text { caretaker } \\
\text { conventions. } \\
\text { Restrictions on } \\
\text { government } \\
\text { advertising }\end{array}$ & $\begin{array}{l}\text { Full caretaker } \\
\text { conventions - } \\
\text { status quo } \\
\text { policy (ie no } \\
\text { policy } \\
\text { innovation, } \\
\text { major } \\
\text { appointments } \\
\text { or major } \\
\text { contracts) }\end{array}$ & $\begin{array}{l}\text { Full caretaker } \\
\text { conventions - } \\
\text { status quo policy } \\
\text { (ie no policy } \\
\text { innovation, } \\
\text { major } \\
\text { appointments or } \\
\text { major contracts) }\end{array}$ & $\begin{array}{l}\text { Full caretaker } \\
\text { conventions - } \\
\text { status quo } \\
\text { policy (ie no } \\
\text { policy } \\
\text { innovation, } \\
\text { major } \\
\text { appointments } \\
\text { or major } \\
\text { contracts) }\end{array}$ \\
\hline $\begin{array}{l}\text { Constitutional } \\
\text { position of } \\
\text { cabinet }\end{array}$ & $\begin{array}{l}\text { Ministers exert } \\
\text { legal powers } \\
\text { and } \\
\text { constitutional } \\
\text { responsibilities } \\
\text { (the Governor- } \\
\text { General } \\
\text { continues to } \\
\text { have advisers) }\end{array}$ & $\begin{array}{l}\text { Ministers exert } \\
\text { legal powers } \\
\text { and } \\
\text { constitutional } \\
\text { responsibilities } \\
\text { (the Governor- } \\
\text { General } \\
\text { continues to } \\
\text { have advisers) }\end{array}$ & $\begin{array}{l}\text { Ministers exert } \\
\text { legal powers and } \\
\text { constitutional } \\
\text { responsibilities } \\
\text { (the Governor- } \\
\text { General } \\
\text { continues to } \\
\text { have advisers) }\end{array}$ & $\begin{array}{l}\text { Ministers exert } \\
\text { legal powers } \\
\text { and } \\
\text { constitutional } \\
\text { responsibilities } \\
\text { (the Governor- } \\
\text { General } \\
\text { continues to } \\
\text { have advisers) }\end{array}$ \\
\hline Duration & $\begin{array}{l}\text { Finite duration } \\
\text { (period } \\
\text { between } \\
\text { dissolution of } \\
\text { Parliament and } \\
\text { the general } \\
\text { election) }\end{array}$ & $\begin{array}{l}\text { Finite duration } \\
\text { (period between } \\
\text { dissolution of } \\
\text { Parliament and } \\
\text { the } \\
\text { appointment of } \\
\text { incoming } \\
\text { Ministers) }\end{array}$ & $\begin{array}{l}\text { Negotiation } \\
\text { periods can vary } \\
\text { in duration. } \\
\text { Prolonged } \\
\text { interregnum } \\
\text { could lessen } \\
\text { restrictions on } \\
\text { government and } \\
\text { require it to act } \\
\text { more like a non- } \\
\text { caretaker } \\
\text { administration }\end{array}$ & $\begin{array}{l}\text { Negotiation } \\
\text { periods can } \\
\text { vary in } \\
\text { duration. } \\
\text { Prolonged } \\
\text { interregnum } \\
\text { could lessen } \\
\text { restrictions on } \\
\text { government } \\
\text { and require it } \\
\text { to act more like } \\
\text { a non-caretaker } \\
\text { administration }\end{array}$ \\
\hline $\begin{array}{l}\text { What happens } \\
\text { when urgent } \\
\text { matters of } \\
\text { significance } \\
\text { arise? }\end{array}$ & $\begin{array}{l}\text { The } \\
\text { government } \\
\text { can still act } \\
\text { with full } \\
\text { executive } \\
\text { powers }\end{array}$ & $\begin{array}{l}\text { Government } \\
\text { acts after } \\
\text { consultation } \\
\text { with leader/s of } \\
\text { incoming } \\
\text { government }\end{array}$ & $\begin{array}{l}\text { Government } \\
\text { consults some, if } \\
\text { not all, } \\
\text { opposition party } \\
\text { leaders before } \\
\text { taking decisions }\end{array}$ & $\begin{array}{l}\text { Government } \\
\text { consults some, } \\
\text { if not all, } \\
\text { opposition } \\
\text { party leaders } \\
\text { before taking } \\
\text { decisions }\end{array}$ \\
\hline
\end{tabular}




\begin{tabular}{|c|c|c|c|c|}
\hline Problems & $\begin{array}{l}\text { An unusually } \\
\text { long election } \\
\text { campaign can } \\
\text { produce an } \\
\text { undesirable } \\
\text { policy hiatus }\end{array}$ & $\begin{array}{l}\text { No problems } \\
\text { providing } \\
\text { parties obey the } \\
\text { conventions }\end{array}$ & $\begin{array}{l}\text { Prolonged lack } \\
\text { of inaction could } \\
\text { (a) threaten the } \\
\text { public interest \& } \\
\text { (b) undermine } \\
\text { perceived } \\
\text { government } \\
\text { legitimacy }\end{array}$ & $\begin{array}{l}\text { Prolonged lack } \\
\text { of inaction } \\
\text { could (a) } \\
\text { threaten the } \\
\text { public interest } \\
\text { \& (b) } \\
\text { undermine } \\
\text { perceived } \\
\text { government } \\
\text { legitimacy }\end{array}$ \\
\hline
\end{tabular}

A second issue is whether the caretaker conventions require further clarification and elaboration. A key feature of the current arrangements is that the conventions are couched in terms of general principles rather than strict, highly specific rules. This enables complex policy issues and unforeseen problems to be addressed on a case-bycase basis by the caretaker government without its options being unduly constrained by a tightly defined code of conduct. Admittedly, the flexibility provided by the current approach carries certain risks, but in our view these are not sufficiently great to warrant the adoption of a much stricter policy regime, nor indeed the statutory codification of the existing conventions. In short, while there are risks under the present arrangements, the potential problems of conducting the business of government in the context of a rigid caretaker code with little scope for ministerial discretion are likely to be worse. What is more, given the variety of circumstances in which caretaker governments can occur (as illustrated by Table 1), it is likely to be very hard to come up with detailed, yet sensible, rules that could adequately address every conceivable contingency.

Having said this, the current conventions are not perfect, and minor modifications may well be useful. One issue which requires further attention, for instance, is the application of the conventions to the Crown entity sector. In this context, the experience of late 1996 suggests that while public servants in the departmental sector had little difficulty adjusting to, and complying with, the spirit of the new caretaker environment, many within the Crown entity sector believed that it was simply business as usual. ${ }^{48}$ There were also concerns raised by the readiness, if not eagerness, of the boards and senior managers of some Crown companies to lobby the coalition negotiators on behalf of their organizations. On another front, were New Zealand to experience a very lengthy caretaker period, there would almost certainly be a need for the conventions to be relaxed somewhat so that the normal business of government - including the preparation of the budget and the presentation of legislation to Parliament - could continue without undue delay. In such circumstances, there would probably need to be some kind of agreement

48 C James, above n 23,36 . 
between the parliamentary parties (or at least a sufficient number of them) over those matters, on the one hand, where the incumbent government could be left to take new initiatives (presumably with appropriate consultation) and over those matters, on the other hand, which definitely should be deferred until the political situation had been clarified.

Finally, the evolution of the caretaker conventions in New Zealand and the advent of MMP prompt several other issues. One of these relates to who should "guard" constitutional conventions of this kind and the adequacy of the current mechanisms for providing governments with advice on matters of a constitutional nature - for instance, via the Secretary of Cabinet, the Secretary of Justice and the Solicitor-General. Another issue is the possible merit of measures designed to limit, or at least reduce, the likely duration and frequency of caretaker periods. There are at least three main options in this regard: the introduction of a fixed parliamentary term (which would reduce the potential for early, and thus more frequent, elections); the institution of a constructive vote of noconfidence (which would reduce the potential for lengthy caretaker periods mid-term); and an amendment to section 19 of the Constitution Act 1986 designed to reduce the period between the holding of an election and the summoning of Parliament (which would provide a political incentive for a faster process of government formation, as well as enabling Parliament to officially sanction or reject specific proposals advanced by a caretaker government). A full analysis of these options is beyond the scope of this article. However, in our view each of these proposals has merit and deserves serious consideration.

\section{CONCLUSIONS}

This article has charted the evolution and clarification of New Zealand's caretaker conventions since the mid-1980s and considered their application during the relatively protracted interregnum following the first MMP election in 1996. In some respects it is remarkable that it has taken almost a hundred years since the development of a modern party system in New Zealand for the conventions surrounding caretaker periods to become more clearly enunciated and firmly established. This of course reflects the relative lack of serious constitutional crises and the durability of New Zealand governments, the product in turn of an electoral system which delivered long periods of single-party majority government. With the advent of proportional representation, the prospect of highly stable single-party majority governments has been greatly reduced. Instead, there is every likelihood that most governments will be majority coalitions, minority coalitions or single-party minority administrations. In each instance, the process of government formation is likely to be more protracted than has hitherto been the case and the governments which are formed will probably be less durable. Accordingly, more regular and lengthier caretaker periods are to be expected - at least if MMP endures. 
The evidence to date suggests that the current conventions governing caretaker periods have proved to be relatively robust and that they enjoy sufficient multi-party commitment to ensure that they will be applied in good faith by future caretaker administrations. At the same time, there is scope for greater clarification of the circumstances in which the conventions should apply and their implications for the Crown entity sector. Additionally, further attention should be given to the adoption of various measures designed to reduce the potential under MMP for political uncertainty and instability. Were such measures to be successfully implemented they would, in turn, have the effect of reducing both the likelihood and duration of caretaker periods. This would be desirable from both a constitutional and political perspective. 